\title{
THE PROFITS AND VOLUME OF CAPITAL.
}

Are the profits of capital regulated by natural law, and what determines the volume of capital in a country? Why are the profits of capital greatest among people the least civilized, and why greater in new countries than in old? What prevents the gains from compound interest absorbing again and again the wealth of the world? And lastly, should the land and franchise values of a country be included in its stock of capital? The purpose of this paper is the attempt to answer these questions and to apply some of the conclusions to present day problems.

Three terms require definition and consideration-nature, man, and that which man makes from nature. Nature and her powers may be called land. Man's activities may be designated labor. Labor applied to land produces capital." In reasoning concerning these elements they must be kept separate, and their products distinct. Rent arises from the use of land. Wages proceeds from labor. Profits (or interest) accrues to the owner from the use of capital.

Rent is that marginal product attributable to location on the earth's surface. It is a free gift of nature or of the "indestructible properties of the soil." Wages are the product resulting from man's activities, whether mental, moral or physical. Profits, or interest, is a product attributable to capital as certainly as rent is the product derived from land and wages from labor.

1 The author of this paper reached his conclusions concerning the theory of interest and capital here presented, and had partly written the manuscript of the paper before he saw Professor Clark's "Theory of Distribution." Mr. Sawin states that "as far as I know I am not under obligations to the work of Clark."-TEB Enitor.

"Karl Knies in " Das Geld," p. 47, defines the capital of a community as its available stock of goods (whether for consumption, acquisition or production) which may be applied to satisfying wants in the future. "Capital is an immediate product of nature and labor, nothing more."-Böhm-Bawerk in "Positive Theory of Capital."

$[420]$ 
Capital means either the concrete objects that man has made for his gratification, or the "value" instead of "volume" of exchangeable commodities, the second meaning always having reference to a ratio of exchange. In the first sense, a ship is the same capital the day it loads its first cargo as it is the day it discharges its last cargo. In the second sense, it may be a capital of half a million dollars the first day, whereas on the last day its capital is its value as junk. Concrete capital is objective. It remains the same from the day it is made to the day it is discarded as of no more use. Value capital is subjective, springing entirely from the mind of man as shown in his desire to exchange his products or supply his needs. Its value is infinite if it is the crust of bread that saves a life, although the crust might have been thrown away by another for whom it had no value. A thing may be worth a million dollars one day, the next day be worthless because something better has been invented to take its place. The use of one term to cover two entirely different conceptions has prevented right conclusions in economic research; and it is only by keeping apart these two forms, and tracing the laws governing each separately that one can avoid current economic confusion and answer the questions just propounded.

Concrete capital, the simplest form, is the first in historic development and furnishes the basis of the second concept. Its most notable characteristic is its perishability. It is constantly turning back to nature, and varies in endurance from that possessed by foods, by clothing, by implements, by buildings, and by coined money, which is, probably, the most durable of useful capital. Nothing man can make endures forever.

In order to study the characteristics of concrete capital, observe its functions, and deduce the laws governing its profits and volume, it will be well to choose an article for illustration the use of which is not influenced by the factor rent. We will assume also that when the article is once 
made, no repairs will be put upon it, since that would introduce fresh capital, and confuse the reasoning. In order to obviate the interference which invention makes with economic adjustment it will furthermore be assumed that the same kind of article will be used without improvement during man's passage from savagery to civilization. We will first study the functions of the single article during its term of usefulness, then include the human factor and see why and to what extent man will increase the number of such articles. By correctly analyzing simple conditions, we may correctly judge of the complex ones of to-day, and feel a confidence in our final conclusions. ${ }^{1}$

Let it be assumed that in an Indian village one man conceives the idea of making, from wild hemp, a net to aid him in fishing, nets not having previously been used by his tribe. After he has made the net he finds that he can catch one hundred fish with the effort previously used to catch ten. Obviously ten fish is still his wages as before and ninety fish is the gross profit of his net. He will not let another use it except he receives ninety fish in payment as it would earn him that much if he used it himself. As long as the capital in nets is restricted to one, his wages will remain ten fish and ninety fish will be the gross profits derived from the net. If the ownership passes to another person the division of the results between profits and wages will remain the same.

It may now be assumed that the net would last five years, and that it would depreciate in quality at a uniform rate. The beginning of the second year the user could catch only eighty fish instead of one hundred, the gross profits having shrunk to seventy fish. The beginning of the third year he could catch but sixty, and his gross profits would be fifty. At the beginning of the fifth year he can catch but twenty, with a gross profit of ten fish; and nearing the end of the

1 "In dealing with complex problems of an advancing economy, the key to success is the separate study of the static forces that constantly act within it." $-J . B$. Clark in his "Distribution of Wealth," p. $6 \mathrm{~T}$.

[422] 
first six months of the year he can catch only eleven, but he will still use the net, for without it he can catch but ten. At the beginning of the seventh month of the fifth year there will be no advantage derived from the use of the net. The owner may use it, but if he does, he will quit when it fails to catch him ten fish; the net having then passed beyond the margin of use. The margin of use is the initial point in the law governing the profits of capital.

The margin of use of capital is perfectly analogous to the margin of cultivation in the law governing the rent of land. The fishing net might be used till near the end of the five years, when it could catch but one fish; likewise land could be cultivated to the desert's edge and yield practically nothing; but such land would be beyond the margin of cultivation, as such net would be beyond the margin of use of capital.

When the gross profits of the new net are seen to be great, other nets will be made; but the gross profits of each net will be the excess of what could be caught without its use until the wants of the tribe for fish can be entirely supplied by fish caught by nets. After this, as nets increase in number, the margin of their use-the marginal nets-will be determined in another manner, viz: by the necessities of the tribe for fish. Four-year-old nets that catch twenty fish will be for a time the poorest ones that it will be necessary to use. They will be on the margin of use, and wages will have risen to twenty fish, the increase of ten fish being accountable to the increased use of nets. The number of nets may now increase until a net more than three years old will be discarded as not needed. As they are on the margin of use furnishing no profit, their catch of forty fish will be the wages of all those engaged in fishing, and all above forty fish that other nets can catch will be gross profits.

The law of marginal capital may be stated as follows: capital on the margin of use is the least productive capital -the poorest capital that the needs of society forces produc- 
tion to make use of. (The margin of cultivation of land is that land the poorest in use to which the needs of society force production.)

The growth of capital as governed or influenced by man's nature may be traced as follows: the great positive deterrent to the accumulation of capital, either as an aid to production or for direct enjoyment, is the shortness and uncertainty of life. To accumulate capital requires labor in excess of that necessary for present needs, and in man's nature there will always be a reluctance to labor when there are uncertainties of enjoying the fruits of it. Although this feeling is modified by a desire to accumulate something for old age, also to provide for family dependents, the great body of humanity is dominated by a stronger impulse to enjoy capital than to replace it.

There are two other reasons why profits are required of capital, the failure to properly judge future wants, and the lack of will-power to enforce judgments. ${ }^{1}$ With uncivilized man these are the main causes why large profits are insisted upon; but these causes decrease as man becomes civilized, and will disappear should he become strictly economic. In this may be seen the explanation of the large profits of capital in lower civilizations. The interest rate in old countries is a measure of their progress.

The term "gross profits" requires examination. As it has cost labor to make a net, something must evidently be deducted from the gross profits that will be equivalent at the time the net is discarded to the labor employed in making it; or as business men would say, it must provide a sinking fund to replace itself when worn out. It will be observed that as the margin of use of capital rises, this sinking fund must be a larger proportion of the gross profits; as we have seen, wages have risen and therefore the cost of making has

\footnotetext{
1 Read Böhm Bawerk's "Posilive Theory of Capital," p. 254 ; Professor Smart's translation for somewhat similar views, and to whom the writer acknowledges obligation.
} 
been increased; at the same time the period of usefulness of the article has been shortened.

If at the end of two years the total profits of a net will exactly pay for the cost of making a new one, the point of the reproduction of capital from its earnings has been reached. If the needs of society force the production of fish no further than those caught with two-year-old nets, profits, or interest on capital in nets, will have disappeared; for wages will have risen to sixty fish, and all above that caught by the nets will but pay for the cost of making new ones. It is conceivable that nets might be so plentiful that those more than a year old could be dispensed with, but we see that the total profits in this case would be much less than the cost of making the nets. Eighty fish would be the wages of labor, the total catch of one-year-old nets, while it would require all the fish above sixty that could be caught for two years to pay for the nets.

The natural limit to the production of capital has now been determined. It is the point of the reproduction of capital from its earnings, as modified by the nature of man in considering the shortness and uncertainties of life, and his poor judgments of his future needs and weak will in executing them.

It will be profitable to make some experimental applications of the principles laid down. If all the profits of capital go to reproducing capital, leaving all wages and all rent to go to other purposes, the volume of capital will quickly grow to the point of the complete reproduction of capital. It cannot go above it, as the waste from discarding capital too soon will send it down again. It cannot stay below it, as the net profits of capital longer used (necessitating lower wages) will quickly raise the volume again. If the volume of capital is stationary all the net profits of capital are being absorbed in consumption. If the volume of capital is growing the net profits, less the net growth, gives the amount absorbed in consumption. 
If the net profits of any capital, however small, be constantly turned to the reproduction of more capital, time alone is required to bring all capital to the reproductive point; $i$. $e$, such sum of capital will itself absorb the wealth of the world. It is the partial application of this principle that has brought to its present magnitude the great Rothschild fortune and is producing in our own country the billion-dollar trusts.

In a strictly economic society, and after the volume of capital has adjusted itself, every improvement in machinery increases wages through the rise in the margin of use, due to the increased product. We may know this, but we cannot measure its amount and determine its permanency until we ascertain its effects upon the volume of consumption, and how it will affect the numbers of population. If consumption remain the same as before the total increase goes to wages. An increased consumption means a relatively less increase in wages. If consumption increases in the same proportion as increased product (it cannot go above it) wages cannot rise from this factor. If population remains the same the whole increase will go to wages. If population rises relatively with increased product (it cannot go above it) the rise in wages will be proportionately less. The actual change will be a composite resulting from these two effects.

A large part, possibly 90 per cent or more, of present wages was originally the profits of capital, but upon the increase of capital it has gone to wages by the rise in the margin of use. To realize this it is but necessary to imagine what the effect upon labor would be were the results of past labor to be suddenly destroyed.

If this analysis of capital is correct there is no "surplus value," as Karl Marx supposed, and no exploitation of labor in the way the Socialist would have us believe. The analysis reveals, however, a scientific reason for the socializing of capital. The life of the individual is short and uncertain. This justifies him, in any situation in which he may find 
himself, to demand a surplus profit on any capital he may wish to accumulate; for if capital is at the reproductive point, and yields no interest, his income from wages alone would be as much as if he owned a million dollars' worth of capital also. The life of the nation being so nearly perpetual when measured by individual life the nation could, without violating economic law, maintain the volume of capital at the reproductive point. The individual's ignorance of his needs, and his lack of will privately to maintain the requisite supply of capital, would be rectified by the greater knowledge and power of the state. This, however, is but one side of the account. It must be balanced by a public civil service as perfect and economical as private employment and a public honesty equal to private honesty. These two things having been secured the socializing of capital may properly be considered. Public ownership could then accomplish more than private ownership.

The value form of capital is of a more complex nature. Its simplest manifestation is in the exchange of " consumption goods." The normal static value of these is their labor cost of production from land on the margin of cultivation with capital on the margin of use. It being, however, impossible to forejudge the volume of production, because as the result of favorable or unfavorable seasons, the ignorance of what others are doing to supply the demand, or the changes of fashion in consumption, the market price will fluctuate with approximate equality above and below the cost line.

If the world's wheat crop is large in any year the total wheat values for that season may be less than they would have been with a two-thirds crop. To capture these additional values, it is said, whole cargoes of spices have been dumped overboard at sea, the owners, controlling the total output, having bought at prices governed by large supply. Trusts are not a disadvantage to the public because they produce cheaply, but because, by controlling the output, 
they can limit production and thereby extort scarcity values. These acts being anti-economic are immoral, and should be made criminal. Since the evils of monopoly arise from the private ownership of natural elements, the simple remedy is the public ownership of those elements, thereby allowing free enterprise and the most abundant production.

The normal static value of "tools of production" when new is the same as that for consumption goods, and in addition to this it must agree with their future earning power, discounted in proportion to their productive qualities during their term of usefulness. When tools cease to be new the cost rule ceases to apply and their earning power governs their value. The value of a locomotive or a mill will be its future earning power, discounted for the waiting; but when they are new this value must also equal their cost of production, otherwise they would not have been made.

Coined money is a tool that on first thought appears to be value capital, but it belongs to the concrete variety. Its value, in the long run, is its labor cost of production at marginal mines by the use of marginal machinery. It is perishable in that it is always liable to be lost in handling and by abrasion. A hammer or a shovel may be employed for a dozen useful purposes, but a coin can perform but two uses, act as a common measure of value or effect exchanges. The value of all other things, being measured by the value of the coin unit, makes the coin appear as value capital, when in fact it is concrete capital. Being used as the tool that facilitates almost innumerable exchanges, the coin and its representatives conveniently assume the minute subdivisions necessary to do the work in the most economical manner. As the tools of railroad construction are accumulated where railroads are being built, so the tools of exchange are accumulated where there is the most use for them, as in the markets of great cities.

This discussion has now reached the point where " interest" may properly be defined. When the net profits of [428] 
capital are spoken of as bearing a certain ratio to the parent capital, computed for a definite time, the ratio is properly expressed decimally as a certain per cent of interest. The term interest always presupposes the comparing of two quantities for a period of time. The value of concrete capital, sinking as its future earning power decreases, makes the interest of value capital approximately the same in the same market. The time element in the profits of capital has a negative side as well as a positive one. The positive side we may express in this way : time is necessary for the profits of capital to show themselves. Negatively, we may say: time, together with wear, destroys all capital.

"Capital" is used here with a more comprehensive meaning than economists generally give it, but the term, nevertheless, has a relatively restricted scope. Capital springs only from labor (man's activities) applied to land (nature's gifts). Furthermore, a thing to exist at some future time only, cannot be said to exist to-day. We recognize this truth in the homely caution, "Don't count your chickens before they're hatched." It is a true axiom that "I,ike things only can be measured by like."

When a man had the power to take for his own use the surplus earnings of another, he could sell that power and its value was computed in the way we now compute the value of a tool-i.e., the value was the probable future net earning power discounted by the owner to recompense him for waiting for the enjoyment of the product of his slave's labor. The slave might be worth $\$ 2,000$; or, if he had been taught a trade, $\$ 4, \infty$. A slave-owner shipwrecked and naked on a desert island with ten companions, his slaves, in the same situation as himself, and about to be rescued by a passing ship, might be worth $\$ 40,000$ and have all his "capital" according to the old idea, with him. Labor applied to land did not make his slaves, and could not, therefore, be capital according to our ethical conception of the term. The product of the slave's labor must exist before it can be called 
capital. Man's power over another cannot be measured in shovels or axes, wheat or dollars. An advance in ethics was made, a great moral idea prevailed; "capital" in slaves was destroyed.

A parent educates his son to follow successfully a very profitable trade or profession. His proficiency is not capital; it is himself. He is a more perfect man than he would otherwise have been or than his early uneducated playmate is. No labor has been spent on land. If he does something that his ignorant mate could do equally well, it is of no more value than if the other had done it. Knowledge cannot be compared with plows or hoes; but only with ignorance. Developing man's latent powers is not producing capital ; it is making the man.

A patent is a grant of power, by government, giving a monopoly of the making of an article to presumably the first inventor or his representatives. The plan of the article is not a product of land, but of the inventor's mind. To become capital it must first become embodied in material. The idea may have a value but it is not a thing. The granting of one power by government can only compare with the granting of other powers by government. However wise or unwise the grant of a patent may be, it is only the power to transfer wealth from the slower-minded to a fortunately quicker-minded one. The people might possibly be better served by directly rewarding inventors from the public treasury, and granting no monopoly to any one.

A man of business builds up, by fair dealing and progressive methods, a valuable reputation for his firm. The advantage he derives thereby is not the profits of his capital, but the wages of his labor. It is his pay for the exercise of his moral qualities of honesty and enterprise. Enterprise can be compared only with the lack of it, and honesty with dishonesty.

A railroad furnishes transportation facilities for a certain section of country. With its building goes a natural monopoly of the freight and passenger service of its territory. No 
other road, unless for speculative purposes, will be built if one is sufficient to do the business, for a competitor would only divide the traffic and might reduce the rates. A reduction in rates might be an economic loss to the owners. A division of the traffic might be to the disadvantage both of the owners and the public. The maintenance of two roads where one was sufficient could not be otherwise than an economic loss-both in the building and in the operating. The rates, it will be seen, representing the profits of capital, are not governed by the laws that regulate the profits and volume of capital, but by that of "all the traffic will bear." This may be in extreme instances several times the normal profits on the labor spent in construction and maintenance. This monopoly power, allowing a higher than the normal rate of interest, is the foundation for the issuance of watered stock, so prominent a feature in all private corporations performing public functions through natural monopolies, also of those performing private functions through the private ownership of natural elements.

Is watcred stock capital? It springs not from labor but from the power of appropriation. It represents not things in existence but that which may be in existence at some future time. Rights to things can only originate with things, and must by nature lie with him that produces them. Watered stock accordingly cannot be capital..$^{\mathrm{x}}$

\footnotetext{
1 Economics has its basis in ethics. Until man's right to personal liberty was recognized there could be no freedom of contract-the hypothesis which Adam Smith used in his Wealth of Nations, and which Ricardo and Malthus further employed in their determination of the Law of Rent and of Population. If we may judge of the future by the past, we may expect the future extension of economic knowledge to be the result of a further and closer determination of the rights of man in and to property. Property rights will become more sacred. The wages of labor will belong, without division, to the laborer, be he superintendent or superintended; whether he exercise his muscles, his mind or if you please, his morals. The profits of capital will belong, without division, to those who have the right of ownership in capital, whether they be individual, corporation, city, state or nation. Wealth, the product of social growth (economic rent), will belong, without division, to the society whose presence produces it, and those things that are planted in the earth by nature to serve man's wants will belong, by right, equally to all God's children.
} 
It only remains to make application of the foregoing principles to land to answer whether land values should be included in the capital of a country. Land values are the reflex on land of the normal interest rates on value capital. As the uncertainties of life will cause man to require a net profit on concrete capital, or a rate of interest, the same influences will govern the man having the power of appropriating to his own use the economic rent of land. If his capital earns him Io per cent he will consider the land rent he receives to be the same ratio to the land's value. If he wishes to "sell his land" he will expect to receive ten times the yearly rental. If the interest rate is 5 per cent he will expect to receive twenty times the annual rental. Stating it in another way, we may say the " right" of land ownership being a right to the perpetual rental, its "value" will be the sums of the perpetual rental discounted at the prevailing rate of discount to the present worth at the present time.

Free gifts of nature cannot be a product of labor, nor have they any relation to labor products. They cannot be measured by the units employed in the measurement of capital, because, having different sources and natures, they are entirely different in kind. To assert otherwise is to claim as sensible such queries as, "Which has the greatest cost of production, a cucumber or a sunbeam, a sewing machine or Niagara Falls, a bushel of wheat or a town lot?' If the items of capital must exist before they can be enumerated, how can the products of nature or of labor that will appear upon the earth as long as man inhabits it be claimed and listed as present day capital? They cannot, and land values have no proper place in an enumeration of capital.

\footnotetext{
1 In Professor Hadley's Economics, par. 320, he says: "Economic rent is chiefly due to foresight in investment." But suppose that the institution of private property in land did not exist, there could then be no investment. Would a rich gold or iron mine then be of no more value than a sand bank? Would they yield no economic rent in proportion to their richness or barrenness? Would there be no difference in the productive powers of a fertile valley and a desert plain?
} 
The United States census report of total wealth must be analyzed and the different items segregated before it can be properly understood. If half the eighty billions of weaith represents the value of concrete labor products the balance, or forty billions, simply represents future expectations. These forty billions are the capitalized yearly earnings, from land and franchises, at the prevailing rate of interest. Another country, having the same population and labor products, and with equal natural and franchise advantages, but whose people require double the rate of interest, would list this value at twenty billions. Another country, with the same population and labor products, and with equal natural and franchise advantages, but whose people were satisfied with half the interest rate, would put down this item of their wealth at eighty billions. If a large stock of national capital is desired we have but to forego the natural right to personal freedom, re-establish slavery, have the number of slaves about half the number of people. We might then put our stock of national capital at about double the present inflated figures.

San Francisco, Cal.

Wirhtam Grant Sawin. 